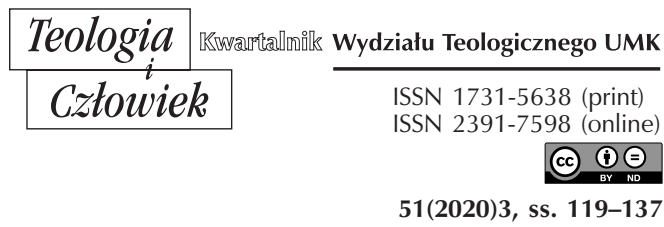

PRZEMYSŁAW SOŁGA

UNIWERSYTET PEDAGOGICZNY W KRAKOWIE

PRZEMYSLAW.SOLGA@GMAIL.COM

ORCID 0000-0002-0670-8857

\title{
ROLA AUTORYTETU W KATOLICKIEJ ETYCE WYCHOWAWCZEJ. WSPÓłCZESNOŚĆ I HISTORYCZNE ANTECEDENCJE
}

DOI: http://dx.doi.org/10.12775/TiCz.2020.042

Streszczenie. Celem artykułu jest ukazanie roli, jaką wedle katolickiej etyki wychowawczej odgrywają autorytety w wychowaniu dzieci i młodzieży, a także dorosłych. Główny punkt odniesienia stanowią autorytety wychowawców, przede wszystkim zaś rodziców. Autor wyselekcjonował zagadnienia i przedstawił je na podstawie wybranej literatury przedmiotu, a także wybranych źródeł. Historyczne antycypacje uwzględnione w pracy stanowią uzupełnienie i mają służyć lepszemu zrozumieniu poruszanych zagadnień.

Słowa kluczowe: katolicka etyka wychowawcza; autorytet; wychowanie.

Abstract. The role of authority in Catholic educational ethics. Present and historical antecedents. The aim of the article is to present the role that, according to Catholic educational ethics, is played by authorities in educating children and the youth, as well as adults. The main point of reference are the authorities of educators, especially parents. The author chose relevant issues and introduced them on the basis of selected literature referring to the subject but also on the grounds of selected sources. Historical anticipations included in the paper are complementary and contribute to better understanding of the issues raised.

Keywords: Catholic educational ethics; authority; upbringing. 


\section{DZIECKO PODMIOTEM WYCHOWANIA}

Współczesna, katolicka refleksja nad metodami wychowawczymi jest antropocentryczna, jednak ukierunkowana w coraz większym stopniu na formację wychowawców. Arkadiusz Robaczewski w swojej refleksji nad współczesnym wychowaniem wskazuje na „nieadekwatną koncepcję człowieka”: „bez gruntownej znajomości podmiotu pedagogiki nie jest przecież możliwe sformułowanie ani celu wychowania, ani wskazanie czynności, które do tego celu mają prowadzić"1. Humanitarne wychowanie znajduje rację bytu tylko wtedy, gdy odnosi się do wartości personalizmu, ponieważ nie tylko wychowuje się osoby, ale też kładzie nacisk na coraz większe stawania się osobą. Wychowawca nie jest samowolnym artystą i nie ma on do czynienia z „bezkształtną masą”, z zadaniem kształtowania czegoś wedle własnego widzi mi się $e^{2}$. Wychowawcy sami muszą wdrażać wartości, które (z założenia) skrupulatnie usiłują wpoić swoim wychowankom. Własny przykład przynosi bowiem o wiele bardziej owocny skutek wychowawczy niźli multum wypowiedzianych słów, jakkolwiek nie byłyby one pouczające ${ }^{3}$.

Pytanie o współczesne metody wychowawcze nieodłącznie łączy się z pytaniem o podmiot wychowania. Jest nim zawsze człowiek, niekoniecznie dziecko. Pytanie o człowieka jest zawsze pytaniem otwartym. „Człowiek wie dziś coraz więcej, lecz sam nie wie, kim właściwie jest” konkluduje Beata Kołodziej. Pytania o naturę człowieka i przyznanie mu praw ludzkich w okresie prenatalnym wbrew pozorom często towarzyszom dywagacjom na szczeblu politycznym w przypadku prawa stanowionego i są kluczowe dla właściwego rozumienia poszczególnych spraw, mogąc zarazem poświadczyć niejednokrotnie sprzeczność litery prawa z jego duchem. Warto na przykład odnieść się do prawa międzynarodowego: „W rozumieniu niniejszej konwencji dziecko oznacza każdą istotę ludzką w wieku poniżej osiemnastu lat, chyba że zgodnie z prawem odnoszą-

1 A. Robaczewski, O antropologię dla pedagogiki, „Cywilizacja” 2003, nr 7, s. 87.

2 J. Wilk, Wychowawca wobec pytania: „Kim jest dziecko”, w: Oblicza dzieciństwa, red. D. Kornas-Biela, Lublin 2001, s. 185.

3 R. Czekalski, Personalistyczne postawy wychowania, Warszawa 2009, s. 43.

${ }^{4}$ B. Kołodziej, Wartość dziecka we współczesnym świecie, w: Oblicza dzieciństwa, s. 142 . 
cym się do dziecka uzyska ono wcześniej pełnoletniośćc". Tyle na temat „definicji” pojęcia dziecka mówi nam Konwencja Praw Dziecka, której - rzecz ciekawa - po dziś dzień nie ratyfikowały Stany Zjednoczone. Jest tam określona jedynie górna granica wieku, która może kwalifikować do pojęcia dziecka. Warto o tej granicy pamiętać - dziecięctwo nie kończy się przecież w okresie dojrzewania, ale trwa aż do osiągnięcia dorosłości, którą domniemywa się w wieku uzyskania pełnoletniości ${ }^{6}$. Co ciekawe, niebagatelną, jeśli nie kluczową rolę w powstaniu rzeczonej Konwencji odegrała strona polska. I to w polskim prawie można znaleźć bardziej precyzyjne odniesienia, jeśli chodzi o zadane wyżej pytania. W ustawie o Rzeczniku Praw Dziecka, znajduje się taki oto zapis: „W rozumieniu ustawy dzieckiem jest każda istota ludzka od poczęcia do osiągnięcia

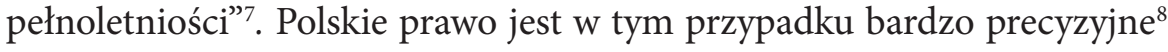
i gdyby ktoś miał wątpliwości, wystarczy go odesłać do powyższej pozycji prawa stanowionego. Warto dodać, że nie jest to nowe rozwiązanie, ale wynikające $z$ historycznych tradycji. W czasach starożytnych uważano płód za człowieka - w poematach Homera dziecko poczęte, noszone w łonie matki, ma taką samą wartość jak to, które się urodziło, nie ma między nimi rozróżnienia ${ }^{9}$. Teologia katolicka mówi o tym, że embrion rozwija się samoistnie, nie „od zewnątrz” - zewnętrzne czynniki warunkują jedynie jego prawidłowy rozwój, ale nie stanowią o jego istocie. Degradacja godności człowieka jest równoznaczna z niszczeniem sensu osoby, a co za tym idzie unicestwieniem człowieka ${ }^{10}$. Jednak ta godność nie wynika wyłącznie z jego natury „ad intra” - od wewnątrz, ale też „ad extra” - od zewnątrz. O tym, że człowiek jest istotą wyjątkową, także

${ }^{5}$ Konwencja o Prawach Praw Dziecka przyjęta przez Zgromadzenie Ogólne Narodów Zjednoczonych dnia 20 listopada 1989 r., Dz. U. z 1991 r., nr 120, art. 1.

${ }^{6}$ Należy mieć na uwadze fakt, że termin „pełnoletność” odnosi się do wieku osoby, a „dojrzałość” do jej osobowości.

7 Ustawa z dnia 6 stycznia 2000 r. o Rzeczniku Praw Dziecka, Dz. U. z 2000 r., nr 6, poz. 69, art. 2. ust. 1.

${ }^{8}$ W tym miejscu warto zadać pytanie, jak często Rzecznik Praw Dziecka podejmuje inicjatywy w celu ochrony praw dzieci znajdujących się w prenatalnym stadium rozwoju.

9 ks. M. Gilski, Początkowe stadia życia ludzkiego wedtug Homera, „Polonia Sacra” 2013, nr 1 (32), s. 12.

10 Tamże. 
w wymiarze fizycznym, spowszechniała tak bardzo, że niektórzy w ogóle o tym zapomnieli albo po prostu z pewnych powodów nie chcą pamiętać. Obecnie przypomina się często, że matrycą prawidłowego rozwoju psychicznego i duchowego jest właściwy rozwój fizyczny. Ale jednak „obraz boski w człowieku jest obrazem ucieleśnionym, a on sam jest obrazem materialnym niematerialnej Trójcy"11. W pedagogice chrześcijańskiej istotne jest traktowanie sensu stricto człowieka jako osoby w pełnym jego wymiarze: zarówno fizycznym, psychicznym, jak i duchowym. Zaniedbanie któregokolwiek z tych komponentów wpływa negatywnie na rozwój całej osoby. Dlatego też w relacji osobowej ważny jest nie tylko kontakt osób mających świadomość posiadania określonej godności, ale też osób posiadających lub pretendujących do posiadania pewnych wartości, które ową niepowtarzalną osobowość konstytuują. „Realizacja właściwości człowieka widzianego integralnie (jako istota fizyczno-psychiczno-duchowa) powinna obejmować wszystkie jego sfery - fizyczną i emocjonalną, poznawczą i moralną, estetyczną, społeczną itd." ${ }^{12}$.

\section{KONCEPCJE WYCHOWAWCZE A WYZWANIA CZASÓW WSPÓŁCZESNYCH}

Można w tym miejscu przywołać dwie koncepcje filozoficzne odnoszące się do procesu wychowania, a mianowicie, obiektywizm aksjologiczny i subiektywizm aksjologiczny. Protoplastami obiektywizmu aksjologicznego byli Sokrates i Platon - zakłada on, że wartości są niezależne od człowieka i jakichkolwiek czynników, istnieją „,ad extra” w stosunku do człowieka, są stałe i niezmienne. W opozycji do niego stoi subiektywizm aksjologiczny, w którym wartości są wytworzone na gruncie ludzkiej kultury i zmieniają się z czasem. Obiektywizm aksjologiczny odwołuje się do pedagogiki personalistycznej, a subiektywizm do pedagogiki państwowej ${ }^{13}$. Dla starożytnych Greków wychowanie czy edukowanie dzieci sta-

11 Tamże, s. 277.

${ }^{12}$ K. Olbrycht, Czy dorośli potrzebuja edukacji aksjologicznej?, w: Aksjologia edukacji dorosłych, red. J. Kostkiewicz, Lublin 2004, s. 175.

${ }^{13}$ M Sawicki, Dziecko jest osoba. Szkice $z$ teorii kształcenia $i$ wychowania, Warszawa 1995, s. 34 . 
nowiło synonim kultury; nie było jej częścią, lecz pełnią ${ }^{14}$. „Subiektywizm aksjologiczny w teorii kształcenia łączy się zaś z utylitarystycznym i liberalistycznym podejściem do ucznia oraz procesu nauczania i wychowania. Praktyka i doświadczenie oświatowe wielu krajów Europy pokazują, że obiektywizm aksjologiczny koresponduje z pedagogiką personalistyczną, a subiektywizm - z pedagogiką państwową. Pedagogika państwowa zdaniem pewnych autorów - była i jest zainteresowana nie tylko uformowaniem człowieka w duchu subiektywizmu, np. etycznego, ale także świadomie i planowo wychowuje człowieka w stanie iluzji aksjologicznych, wśród których najbardziej częstą jest iluzoryczna hierarchia wartości ${ }^{15}$.

Wychowanie na gruncie aksjologicznym powinno wskazywać na specyficzną hierarchię wartości, preferując jednocześnie te najbardziej istotne $^{16}$. Dziecko dokonuje $\mathrm{w}$ ten sposób, choćby podświadomie, hierarchizacji wartości, dostrzegając zarazem te rzeczy, które można określić mianem antywartości. Przesadny egalitaryzm i wyrażony w nim relatywny stosunek do jakiejkolwiek hierarchii społecznej pociąga za sobą indyferentny stosunek do hierarchii wartości, ponieważ człowiek, który przestaje wartościować, w istocie nie uznaje żadnych wartości. Wartość relacji osobowej w wychowaniu ucznia zachodzi nie tylko na linii nauczycieluczeń, ale także pomiędzy uczniami. Tymczasem ci ostatni coraz częściej unikają kontaktu bezpośredniego, zastępując go wirtualnym, co stwarza pole do rozwinięcia się nieśmiałości, a w dalszej kolejności introwertyzmu. Z kolei rodzice zazwyczaj ignorują uwagi nauczycieli, obdarowując swoje dzieci coraz to nowszymi zdobyczami techniki ${ }^{17}$. Przynosi to także negatywne skutki: „w bogactwie obrazów i zabaw, człowiek nie tyle tworzy, co wybiera, przez co staje się uboższy, bardziej pasywny i mniej twórczy. Wyobraźnia z kolei to niezależność, warunek wolności i kultury a nawet jest konieczność warunkująca dynamiczny rozwój człowieka we wszystkich jego wymiarach"18. Internet odgrywa współcześnie ogromną rolę

14 Z. Pańpuch, Ideał nauczyciela-wychowawcy w pismach wybranych autorów starożytnych, „Zeszyty Edukacyjne” 2005, nr 3, s. 84.

15 M. Sawicki, dz. cyt., s. 34.

16 R. Czekalski, dz. cyt., s. 44.

17 M. Szast, Samotność w dobie cyfryzacji, „Pedagogika Katolicka” 2012, nr 2, s. 232.

18 J. Koclęga, Funkcja mediów w komunikacji rodzinnej, w: Rodzina podmiotem wychowania i kreatorem komunikacji społecznej, red. N. Pikuła, Kraków 2010. 
w samokształceniu nauczycieli, gdyż umożliwia „szybki i łatwy dostęp do różnorodnej, aktualnej informacji”'19. Zafascynowane i pozbawione obrony wobec świata, osób dorosłych i potęgi mediów dzieci, w naturalny sposób są gotowe przyjąć to wszystko, co jest im podawane: zarówno to co dobre, jak i to co złe. Delikatność i subtelność serca dziecka jest jak miękki wosk, na którym każdy - nawet najmniejszy - nacisk pozostawia ślad ${ }^{20}$.

We współczesnej refleksji pedagogicznej czasem można spotkać się ze stwierdzeniem, że naukowa wiedza rodziców na temat pedagogiki może warunkować efektywność procesu nauczania. Chcąc wychowywać, rodzice muszą zdobyć elementarną wiedzę na temat wychowania; muszą znać jego cele i zasady, aby wykształcić umiejętności wychowawcze ${ }^{21}$. Jest to o tyle istotne, że rodzice wywierają kluczowy pływ na rozwój emocjonalny dzieci. Dziecko poranione psychologicznie przez rodziców w dorosłym wieku może się stać emocjonalnym kaleką, niezdolnym do stworzenia zdrowej, bliskiej więzi z drugą osobą przeciwnej płci. Osoby tego typu angażują się często w bardzo intensywne emocjonalnie związki, które w rzeczywistości nie mają nic wspólnego z miłością, są wyzute z dojrzałej czułości, zastępowanej przez pustą czułostkowość:

poczucie osamotnienia, niekochania sprawia, że pragnienie bliskości drugiej osoby jest tak wielkie, że nie liczą się w tym momencie nawet Boże przykazania; dlatego częstokroć łatwo przychodzi takiej osobie współżycie seksualne, chociaż w związku tym nie ma miłości. [...] Często można się pomylić myśląc, że ktoś kocha, że się zakochał, a tak naprawdę osoba taka nie jest zdolna do zakochania się ${ }^{22}$.

W podobnym duchu Maria Ziemska powtarza za Erichem Frommem: „kochać kogoś, bo się go potrzebuje - to objaw neurotyczny. Potrzebować kogoś, bo się go kocha - to świadczy o zdrowym sto-

19 J. Zielińska, Samokształcenie nauczycieli poprzez media, w: Kompetencje medialne społeczeństwa wiedzy, red. W. Strykowski, W. Skrzydlewski, Poznań 2004, s. 426.

20 Tamże, s. 351.

${ }^{21}$ E. Kopeć, Raport z przeprowadzonych badań dotyczacych diagnozy wiedzy pedagogicznej posiadanej przez rodziców dzieci w wieku przedszkolnym $w$ powiecie kolbuszowskim, „Roczniki Pedagogiczne” 2013, t. 5 (45), nr 1, s. 58.

22 W. Krupiński SJ, Wychowywać miłością, Kraków 2001, s. 18. 
sunku”23. Powstało już wiele quasi-naukowych „poradników” dla osób z dysfunkcjonalnych rodzin, głównie kobiet, które borykają się z tego typu problemami ${ }^{24}$. Jak podkreśla Maria Ziemska, w przypadku doboru partnera „rodzice przez swą obecność dostarczają dziecku wzorów zachowania. Dzieci zrazu ich naśladują, a później w dużej mierze identyfikują się z nimi i chcą być takie jak oni"25. Jest tutaj ukryty ciekawy mechanizm psychologiczny, który powoduje, że kobiety, która miały ojców alkoholików, często dobierają sobie partnerów z chorobą alkoholową. W swoim partnerze próbują znaleźć ojca lub matkę, których niedostatki emocjonalne doświadczyły $\mathrm{w}$ przeszłości ${ }^{26}$. Nie znaczy to jednak, że nadmiar opieki ze strony ojca czy matki nie jest szkodliwy. Dojrzałe rodzicielstwo dąży do usamodzielnienia się dziecka, które jest ostatecznie jego sukcesem. W rodzinie nadopiekuńczej rodzice chcieliby, aby dziecko znalazło sobie małżonka i założyło rodzinę, często namawiając je do tego i dziwią się, dlaczego tak się nie dzieje. Tymczasem dziecku wywodzącemu się $\mathrm{z}$ takiej rodziny najlepiej jest przy mamie i $\operatorname{tacie}^{27}$.

To jednak nie deprecjonuje znaczenia domowego środowiska, to jest pierwszej i najważniejszej w życiu człowieka szkoły, jeśli chodzi o pełnienie ról w rodzinie: „za właściwe zachowanie związane z pełnieniem roli uważane bywa takie, które wyniesiono z dzieciństwa i które w miarę dojrzewania jednostki zostało wzmocnione lub zmodyfikowane przez dalsze doświadczenia, głównie przez kontakty z tzw. „znaczącymi osobami”28. Te tzw. „znaczące osoby” to po prostu autorytety, które pojawiają się w życiu każdego człowieka, w sposób mniej lub bardziej zamierzony. Tymczasem okazuje się, że rodzice coraz mniej czasu poświęcają na rozmowy z dziećmi, większość czasu spędzając przed telewizorem. Obrazują tę tendencję najnowsze badania, wedle których dzieci na oglądanie telewizji poświęcają 3-4 godziny. Wśród 20\% badanych rodziców można stwierdzić, że oglą-

${ }^{23}$ M. Ziemska, Rodzina a osobowość, Warszawa 1979, s. 69.

${ }^{24}$ Zob. np. P. Melody, Toksyczna miłość, Warszawa 2005; R. Norwood, Kobiety, które kochaja za bardzo, Poznań 2016.

${ }^{25}$ M. Ziemska, dz. cyt., s. 143-144.

${ }^{26}$ W. Krupiński SJ, dz. cyt., s. 18.

27 Tamże, s. 21.

${ }^{28}$ M. Ziemska, dz. cyt., s. 77. 
danie telewizji prowadzi do rozluźnienia więzi rodzinnych ${ }^{29}$. Sprzyja także na pewno tzw. postawie chłodu emocjonalnego, równie destruktywnego co postawa nadopiekuńcza.

Z tych wszystkich powodów tak bardzo współcześnie docenia się znaczenie psychologii w naukach pedagogicznych: „psychologia zdobyła sobie $\mathrm{w}$ naukach pedagogicznych kluczowe miejsce. Możemy nawet mówić o zawłaszczeniu pedagogiki przez psychologię, czego efektem jest psychopedagogika" ${ }^{30}$. Gdyby zagłębić się w ten temat, jeszcze bardziej dojdziemy do wniosku, że tego typu sytuacje mogą przynieść efekt przeciwny, odwrotny od zamierzonego. Jak zauważył Arkadiusz Robaczewski, jest wiele

paradoksów, które uderzają nas w życiu codziennym: im więcej mamy pedagogów i psychologów, im gęstsza jest sieć poradni wychowawczych, im więcej mnoży się rozmaitych programów profilaktycznych albo $w y$ chowania do (tolerancji, demokracji, asertywności, akceptacji siebie etc.), tym więcej pojawia się rzeczywistych, wychowawczych problemów, tym więcej osób z rozbitą psychiką, zagubionych, niezdolnych do życia ${ }^{31}$.

Być może jest to twierdzenie na wyrost; wspomniane poradnie mają przecież służyć pomocą $\mathrm{w}$ wyjściu z problemów, a nie ich pogłębianiu. Przyczyny problemów psychologicznych współczesnej młodzieży są bardzo złożone i nie można zamykać ich w klamrach problemów wyłącznie z życia domowego. Nie można skupiać się na antypodach patologii rodzinnych, aby umniejszać autorytet rodziców. Dawniej w rodzinach inteligenckich poświęcano dzieciom pewną ilość czasu w poszczególnych dniach tygodnia. We współczesnym świecie, przesiąkniętym pracoholizmem, jest to trudne, ale możliwe do wykonania. Decyzja o posiadaniu potomstwa wiąże się przecież z pewną odpowiedzialnością i dobrowolną rezygnacją z elementów dotychczasowego, codziennego życia.

${ }^{29}$ S. Juszczyk, Przekazy medialne a czas wolny dzieci w wieku wczesnoszkolnym, w: Pedagogika szkolna i wczesnoszkolna w sytuacji zmiany społecznej, kulturowej i oświatowej, red. S. Juszczyk, Katowice 2011, s. 218.

${ }^{30}$ P. Jaworski, Psychopedagogika - czyli jak psychologia zmienia szkołę, „Cywilizacja. O nauce, moralności, sztuce i religii” 2003, nr 7, s. 67.

31 A. Robaczewski, O antropologię dla pedagogiki, „Cywilizacja. O nauce, moralności, sztuce i religii” 2003, nr 7, s. 87. 


\section{POTRZEBA I KRYZYS AUTORYTETU}

Szukając źródeł kryzysu autorytetu współczesnej rodziny, można się powołać na wiele innych czynników. Imelda Chłodna wskazuje na feminizm, zwłaszcza ten w najbardziej radykalnej formie, deprecjonujący rolę, jaką odgrywa ojciec w rodzinie ${ }^{32}$, a przecież „każde z rodziców może przekazać dziecku coś wyjątkowego, coś innego, ale uzupełniającego się. Właśnie owo rozróżnienie zadań matki i ojca w zasadniczej mierze przyczynia się do jego właściwego wychowania" ${ }^{33}$. I. Chłodna analizuje lansowanie pewnego rodzaju profesjonalizmu w procesie wychowania, gdzie zarzuca się rodzicom brak kompetencji wychowawczych, co skutkuje dobrowolnym zrzekaniem się przez nich własnego autorytetu ${ }^{34}$, który jest przecież niezastąpiony. Nic zatem dziwnego, że coraz więcej rodziców zaczyna wątpić w skuteczność procesu wychowania, pod pręgierzem różnych teorii naukowych, których stale przybywa. $Z$ jednej strony wiele od nich się wymaga, z drugiej ogranicza ich dotychczasowe wpływy, nakładając przy okazji coraz to nowsze obowiązki. Pokłosiem tak zastanej sytuacji jest nic innego, jak właśnie utrata wiary w sens i skuteczność wychowania przez samych rodziców ${ }^{35}$. Beniamin Spock w swojej książce Dziecko - pielęgnowanie i wychowanie z 1946 r. potępił nadmierny autorytaryzm ze strony rodziców, nawołując do wychowania bezstresowego. Widząc tragiczne owoce między innymi swojej książki, którą wielu Amerykanów powzięło za swój przewodnik pedagogiczny, pod koniec życia wydał dzieło: Lepszy świat dla naszych dzieci, krytykując amerykańską rodzinę $\mathrm{w}$ świecie zdominowanym przez liberalizm rugujący moralne zasady wychowania ${ }^{36}$.

Środkiem zaradczym na przedstawione powyżej bolączki współczesnego wychowania może być przywrócenie wartości autorytetu, który

32 I. Chłodna, Autorytet rodziny - dobro czy przeżytek?, „Człowiek w kulturze” 2011/2012, nr 22, s. 152

${ }_{33}$ G. i A. Astrei, P. Diano, Błędy mamy i taty. Praktyczny poradnik dla rodziców, Kraków 2013, s. 58.

34 I. Chłodna, dz. cyt., s. 152.

${ }^{35}$ Więcej na ten temat zob. M. Nowotka, Kryzys współczesnej rodziny, „Wychowawca" 2014, $\mathrm{nr} 7$.

36 J. Wilk, dz. cyt., s. 182-183. 
w dzisiejszych czasach ewidentnie przeżywa kryzys. Istnieje wśród ludzi potrzeba jego posiadania, a badania dowodzą, że im człowiek jest starszy, tym wbrew pozorom bardziej tę potrzebę odczuwa ${ }^{37}$. Psychologia rozwojowa coraz częściej zaczyna interesować się wiekiem dorosłym ${ }^{38}$. Okazuje się, że edukacja aksjologiczna może przyczynić się do bardziej satysfakcjonującego przebiegu ww. okresu życia ${ }^{39}$. Wychowanie z kolei niekoniecznie musi być czymś, czego z czasem przestaje się potrzebować. W czasach starożytnych pokutował pogląd, że dziecko należy wychowywać w możliwie jak najmłodszym wieku, jest to jednak zgubna teoria: pozbawia bowiem dziecko własnej autonomii, predyspozycji, hołdując absurdowi głoszącemu, że jego rozwój jest niejako narzucony z zewnątrz ${ }^{40}$. Jak to słusznie ujął M. Crozier: „jednowymiarowego człowieka epoki przemysłowej zastąpić musi człowiek, który umie podejmować decyzje i jest zdolny do pełnego zaangażowania się: człowiek, który ma zdolność indywidualnego i zbiorowego uczenia się, a więc ucząc się - sam się zmienia"41. Chodzi o uczenie się zarówno w wymiarze indywidualnym, jak i zbiorowym. Psychologia rozwojowa także interesuje się dorosłym okresem życia ${ }^{42}$, gdyż człowieka można wychować niezależnie od tego, w jakim aktualnie jest wieku. Jak słusznie zauważył M. Sales, „w rzeczy samej, nikt nie jest (nie rodzi się) dzieckiem, ale się nim staje i musi się nim stawać codziennie" ${ }^{33}$. Jest o tyle istotne, że to dorośli wychowują dzieci i młodzież, stąd nieodzowność ich właściwego wychowania w myśl zasady „niewychowani nie mogą wychowywać”.

Niewątpliwie, skuteczne oddziaływanie autorytetu musi się wiązać z pewnym posłuszeństwem ze strony ucznia. Jak stwierdził Jan Paweł II:

${ }^{37}$ K. Kosiński, Czy potrzebujemy jeszcze autorytetów?, „Więź” 2001, nr 1 (507), s. 77.

${ }^{38}$ K. Olbrycht, Czy dorośli potrzebują edukacji aksjologicznej?, w: Aksjologia edukacji dorostych, red. J. Kostkiewicz, Lublin 2004, s. 35.

39 Tamże, s. 33.

${ }^{40}$ J. Wilk, dz. cyt., s. 187.

${ }^{41}$ Cyt za: W. Pilch, Człowiek w cywilizacji sieci, w: Logos i etos Cywilizacji zachodu, red. R. Kupczak, M. Jabłoński, Bielsko-Biała 2014, s. 121.

${ }^{42}$ K. Olbrycht, dz. cyt., s. 35.

${ }^{43}$ M. Sales, Honor stawania się dzieckiem, czyli: co oznacza „Czcij ojca swego i matkę swoją, "Communio” 1996, nr 1, s. 22. 
czym innym jest posłuszeństwo dzieci względem rodziców, zanim te dzieci przyjdą do używania rozumu, a czym innym posłuszeństwo dorastającej młodzieży w rodzinie. $\mathrm{O}$ ile to pierwsze jest bardziej ślepe i bezwzględne, bezkrytyczne, to posłuch dorastających czy dorosłych dzieci zależy w znacznej mierze od tego, co rodzice mają im do powiedzenia nie tylko swoim słowem, ale także swoim życiem ${ }^{44}$.

Tomasz Hobbes wskazywał na trzy zasadnicze podstawy, na których opiera się nasze posłuszeństwo, a są nimi: Siła, Autorytet i Władza. Autorytet, w przeciwieństwie do siły, „nie dysponuje środkami przymusu, nie jest w stanie narzucić nam posłuszeństwa siłą. Nasze posłuszeństwo jest dobrowolne, bo ufamy - jak pisze Jan Baszkiewicz - dobrej woli i kompetencji profesjonalnej dawcy poleceń" ${ }^{45}$. Autorytet musi się jednak wiązać z odpowiednio rozumianą „władzą" wychowawcy nad wychowankiem. Naturalny dystans, dzielący nauczyciela i ucznia, w demokratycznym świecie ulega zatarciu ${ }^{46}$, co oczywiście wpływa negatywnie na autorytet nauczyciela. Ze zgrozą i pewnym zdumieniem można zauważyć, że zmniejsza się także dystans pomiędzy rodzicami i ich dziećmi. Tendencje idące w tym kierunku można znaleźć także w literaturze fachowej. Susan Forward w swojej znanej książce pt. Toksyczni rodzice imputuje tradycji judeochrześcijańskiej przesadną cześć okazywaną rodzicom, nawet za cenę własnego upokorzenia ${ }^{47}$. Gdyby jednak zagłębić się dokładniej w to zagadnienie okaże się, że chrześcijańska nauka o szacunku dla rodziców wynika $\mathrm{z}$ prawa naturalnego i niesie uniwersalne, ponadczasowe przesłanie.

Na kartach Biblii można znaleźć wiele odniesień dotyczących szacunku dzieci względem rodziców; jest tam mowa między innym o posłuszeństwie i karności dzieci (Prz 13,24; Hbr 12,8). Stary Testament najpewniej poprzez czwarte przykazanie chciał podkreślić świętość ról pełnionych przez ojca i matkę, jako że poprzez prokreację odwołują się

${ }^{44}$ Cyt. za: K. Wrońska, Osoba i wychowanie. Wokół personalistycznej filozofii wychowania Karola Wojtyły Jana Pawła II, Kraków 2000, s. 76, przyp. 83.

45 T. Konopniuk, Teologia „czwartej władzy”, w: Media wyznaniowe w Polsce 1989-2004, red. E. Kossewska, J. Adamowski, Warszawa 2004, s. 12.

46 D. Zalewski, Nauczyciel wobec ideologizacji szkoły, "Zeszyty Edukacyjne” 2005, nr 3, s. 129.

47 S. Forward, Toksyczni rodzice, Warszawa 2011, s. 26. 
oni do stwórczej mocy Boga ${ }^{48}$. „Czy władza ojca sadysty, który tyranizuje swoje dzieci, również pochodzi od Boga? Przecież Pismo Święte uczy, że wszelka władza pochodzi od Boga!" - zapytał ${ }^{49}$ ktoś kiedyś o. Jacka Salija. Ten odpowiada, że czymś szczególnym było posłuszeństwo wobec władzy świeckiej w czasach apostolskich: prześladowanych chrześcijan łatwo można było sprowokować do buntu, zatracając w ten sposób sens ich wiary poprzez konwersje ze społeczności religijnej w ruch polityczny ${ }^{50}$. Jeśli jednak chodzi o ojców tyranów, historyczne reminiscencje przywodzą na myśl raczej negatywne konotacje, jeśli chodzi o ich władzę w rodzinie. Ojcowie zachowywali przez długi czas największe uprawnienia, jeśli chodzi o osoby wchodzące w skład rodziny i ich majątek. Spoczywały na nich sprawy kultu, i sami decydowali o przyszłości swoich dzieci, decydując o ich zaślubinach lub umieszczając je w klasztorze w celu wykluczenia z sukcesji. Decyzje o zamążpójściu czy przeznaczeniu do zakonu często zapadały jeszcze we wczesnym wieku dziecięcym potomków ${ }^{51}$. To jednak nie przekreśla dzisiejszego znaczenia roli ojca i wartości jego opiekuńczo-wychowawczego autorytetu. Choć w pierwszych latach życia dziecko psychologicznie bardziej jest związane z matką, ojciec jest nieodzownie potrzebny do prawidłowego rozwoju zarówno chłopca, jak i dziewczyny. Chłopcy z domów, w których nie było ojca, są bardziej uczuciowi niż dziewczynki i w tej samej sytuacji jednocześnie bardziej niedojrzali, są zalęknieni i mają problemy w nawiązywaniu relacji z rówieśnikami ${ }^{52}$. Taki autorytet nie może mieć jednak nic wspólnego z despotyzmem: „dziecko najbardziej potrzebuje autorytetu dorosłych i najczęściej odwołuje się do niego $\mathrm{w}$ okresie szkolnym, a głownie w pierwszych 5-6 klasach. Toteż słusznie hindusi, mówiąc o tym okresie, porównują wychowawcę do władcy, a więc tego, kto kieruje dzieckiem, do którego decyzji ono się odwołuje, kogo pyta. Jednakże ta rola rodziców nie powinna mieć nic wspólnego z rolą władcy absolutnego" 53 .

48 J.L. Grajewski, Czcij rodziców, Łomża 1994, s. 35.

${ }^{49}$ J. Salij OP, Szukającym drogi, Poznań 1993, s. 173.

50 Tamże, s. 175.

${ }^{51}$ Historia ojców i ojcostwa, red. J. Delumeau, D. Roche, Warszawa 1995, s. $116-118$.

${ }^{52}$ M. Ziemska, dz. cyt., s. 146.

53 Tamże, s. 103. 
Człowiek, posiadając dar prokreacji, jest na pewno wyróżniony spośród innych stworzeń. Dzięki niej nie tylko tworzy coś nowego, lecz także - właśnie poprzez wychowanie - nadaje temu czemuś kształt. W tym znaczeniu nie jest stwórcą, ale twórcą - przekształca coś, co już istnieje. Jednakże to „tworzenie” jest uzależnione w pełni od jego strony wolitywnej, pomimo tego, że dawcą życia jest sam Bóg. Wsłuchując się w kazania księży egzorcystów, można dojść do wniosku, że jest to jeden z powodów, dla których diabeł nienawidzi ludzkiej seksualności. Prowadzi człowieka do upadku, zwodząc do grzechu, który jako jedyny spośród „siedmiu grzechów głównych” (najczęściej popełnianych) zawsze jest ciężki. Dopomagają mu w tym rodzice młodych ludzi, którzy często nie są zainteresowani moralnością seksualną swoich dzieci ${ }^{54}$. Wychowanie dziecka może przyjąć osobliwie „demoniczny” wymiar, jeśli rodzice, nawet nie do końca świadomie, przeklinają swoje dzieci. Przeklinanie dziecka przez któregoś z rodziców przynosi opłakane skutki w sferze duchowej, może skutkować dręczeniem lub opętaniem diabelskim, przy którym często nieskuteczne są egzorcyzmy ${ }^{55}$. Możliwość przeklinania nie uprawnia do jego stosowania i jest zawsze grzechem. Z drugiej strony każdy rodzic może błogosławić swoje dzieci, które to błogosławieństwo może mieć równie wielką moc.

Czwarte przykazanie ma o wiele szersze znaczenie, niż mogłoby to wynikać z jego treści. Użyty w nim czasownik „kbd” odnosi się bowiem do uznania czyjegoś autorytetu, ze względu na pozycję, jaką zajmuje on w społeczeństwie. Chodzi o uznanie należne komuś, komu się ono należy $(1 \mathrm{Sm} 15,30)^{56}$. Wynika stąd, że wychowanie nigdy nie może być wyzute z autorytetów. Jak słusznie podkreśla M. Sales: „Sens czwartego przykazania rozciąga się na wszelki autorytet fizyczny, moralny, intelektualny czy duchowy, któremu człowiek, zarówno jako jednostka czy też społeczność zawdzięcza wzrost swojego człowieka i bytu"57. Także greckie

${ }^{54}$ G. Tomaselli, Twarza w twarz $z$ demonem. Nietypowy wywiad, Kraków 2015, s. 13. „Jestem bardzo sprytny; aby osiągnąć swój cel w świecie, osłabiam autorytet rodziców" - zob. tamże, s. 10.

55 G. Amorth, Wyznania egzorcysty, Częstochowa 1997, s. 139-140.

56 J. Carron, Sens czwartego przykazania i historia jego interpretacji, „Communio” 1996, nr 1 (91), s. 10.

${ }^{57}$ M. Sales, dz. cyt., s. 23. 
słowo „timao”(czcić) użyte w Nowym Testamencie, odnosi się nie tylko do relacji na linii człowiek-rodzic, czy też osób stojących wyżej w hierarchii społecznej, lecz także do relacji zachodzącej pomiędzy człowiekiem a Bogiem. Oznacza też wdzięczność i rekompensatę daru dla rozwoju danej osoby czy społeczności ${ }^{58}$. Między innymi dlatego Kościół szacunek ze strony uczniów należny nauczycielowi odnosi do czwartego przykazania $^{59}$. Istotne jest też to, że rodzice wychowując swoich podopiecznych jednocześnie sami się rozwijają. Podobnie nauczyciel może podejmować konsekwentnie swoją pracę tylko wtedy, gdy przykłada sporą uwagę do samokształcenia i pogłębiania swoich kompetencji ${ }^{60}$.

Inną kwestię, bezpośrednio powiązaną z posłuszeństwem wobec wychowawców, stanowi problem karności dzieci. Na gruncie wychowawczym niezmiernie ważne są kategorie kary i nagrody. „Lęk przed sankcją czy pragnienie nagrody są uprawnionymi, pierwszoplanowymi motywami działania postulowanego przez wychowawcę w okresie, gdy sam przedmiot i cel moralny działania nie stanowią jeszcze dla wychowanka wartości, ściślej: nie są odczute jako wartość"61. Tymczasem w dzisiejszych czasach mówi się wręcz o „pacyfizmie pedagogicznym” bezstresowego wychowania, które czerpie swoje źródło z filozofii Rousseau i Freuda ${ }^{62}$. Na przykładzie Szwecji można wnioskować, że rezygnacja z karania dzieci w domu i szkole zwiększa ich agresywność w stosunku do rówieśników ${ }^{63}$. Bynajmniej nie należy w tym względzie jednak popadać w przesadę. Ks. Konarski karanie ucznia ograniczał wyłącznie do takich przewinień, jak „upór, krnąbrność i zawziętośćc"64. Oczywiście, nie ma mowy o stosowaniu kar cielesnych, także z powodów dalekowzrocznych - badania dowodzą, że dzieci które doświadczyły kar fizycznych częściej niż pozostałe dekla-

58 Tamże.

${ }^{59}$ Zob. Katechizm Kościoła Katolickiego, nr 2199.

${ }^{60}$ J. Zielińska, dz. cyt., s. 419.

${ }^{61}$ K. Wrońska, dz. cyt., s. 87.

${ }^{62}$ D. Zalewski, Nauczyciel wobec ideologizacji szkoły, „Zeszyty Edukacyjne” 2005, nr 3, s. 125.

${ }^{63}$ M. Wojciechowski, Psucie szkoły, http://www.opoka.org.pl/biblioteka/P/PS/ idziemy201007_psucie_szkoly.html (dostęp: 22.15.2014).

${ }^{64}$ D. Zalewski, dz. cyt., s. 130. 
rują chęć stosowania tego rodzaju kar $\mathrm{w}$ relacji $\mathrm{z}$ własnymi dziećmi ${ }^{65}$. Jednak wśród błędów popełnianych przez współczesnych wychowawców wymienia się m.in. nadmierną pobłażliwość wobec wychowanków, a także uleganie wartościom propagowanym przez środki społecznego przekazu ${ }^{66}$. System kar i nagród nie jest oczywiście idealny i ma swoje wady. Przede wszystkim indukuje w psychice dziecka tzw. motywację zewnętrzną, gdy robi coś tylko po to, aby otrzymać nagrodę, lub nie robi czegoś tylko dlatego, aby nie zostać ukaranym. Na dalszy plan odchodzi tym samym motywacja wewnętrza, opierająca się o imperatyw wynikający z sumienia (robię coś bo wiem, że to jest dobre; nie robię czegoś bo wiem, że to jest złe). $\mathrm{Z}$ tego powodu system kar i nagród jest tylko elementem, a nie głównym tłem właściwego wychowania dzieci.

Nauczyciel buduje autorytet w oczach uczniów przede wszystkim poprzez własny przykład, i jeśli go wzbudzi, wówczas uczeń przekazywaną przez niego wiedzę odbiera jako wiarygodną ${ }^{67}$; ten brak wiarygodności ze strony wychowawców doskwierał dzieciom w Polsce Ludowej, gdzie postawa nauczycieli częstokroć mijała się z głoszonymi przez nich marksistowskimi ideałami, zwłaszcza na takich płaszczyznach jak godność osoby ludzkiej i wychwalana powszechnie równość społeczna ${ }^{68}$. Uwidocznił się wówczas godny pożałowania antyokcydentalizm, zgodnie z którym przekazywano uczniom w szkołach informacje, jakoby w krajach Zachodu, zwłaszcza w USA, dzieci pozbawiane są podstawowych potrzeb i przymierają głodem ${ }^{69}$. Dobrą okazją do wyrażania tego typu poglądów był Międzynarodowy Dzień Dziecka, w czasie którego mówiło się, że tylko socjalizm zapewnia dzieciom prawidłowy rozwój wynikający z beztroskiego dzieciństwa, różnorakich przywilejów, o czym dzieci z krajów kapitalistycznych mogą jedynie pomarzyć ${ }^{70}$. Marksistowskie teorie wychowa-

${ }^{65}$ Z. Brańka, Karanie i nagradzanie dzieci w rodzinie miejskiej, Kraków 2007, s. 78 .

${ }^{66}$ J. Mastalski, dz. cyt., s. 136.

67 Tamże, s. 7.

${ }^{68}$ J. Brynkus, Ideologiczny kształt Dnia Dziecka w Polsce Ludowej, w: W kregu rodziny epok dawnych: dzieciństwo, red. B. Popiołek, A. Chłosta-Sikorska, M. Gadocha, Warszawa, 2014 s. 582.

69 Tamże, s. $582-583$.

70 Tamże, s. 588. 
nia, których zasadniczą dążnością było dążenie do „raju na ziemi”71 były wypaczeniem pro-personalistycznych koncepcji wychowawczych, gdyż nie uwzględniały fenomenu człowieka jako osoby ${ }^{72}$. Nie przeszkadzało to oczywiście autorom, piszącym zwłaszcza w okresie stalinizmu, do pisania własnych elukubracji pod dyktando Wielkiego Brata. W podręcznikach od teorii wychowania $\mathrm{z}$ tamtych czasów (zwłaszcza z okresu stalinizmu) aż roiło się od podobnych frazesów. I tak w podręczniku T. Nowogrodzkiego czytamy: „nie przeżywa więc dorastający w ustroju socjalistycznym buntów przeciw rzeczywistości, nie «ucieka w samotność», w «świat marzeń i złudzeń» [...]. W marzeniach młodzież kreśli i opracowuje projekty nieraz heroiczne i dalekosiężne, które jednak w warunkach ustroju socjalistycznego znajdują tak często pełną realizację"73. Gdzie indziej czytamy, że w warunkach ustrojowych panujących w czasach PRL-u, środowisko może przekazać cenne wartości wychowawcze, jako że socjalizm „jest najpiękniejszą ideą społeczną, jaką zna ludzkość”, o czym mają świadczyć jego „dotychczasowe zdobycze"74. Powszechnie jednak wiadomo, że młodzież nie bez powodu uciekała z krajów socjalistycznych na Zachód, a nie odwrotnie. Zapominano też wówczas, że pedagogika ma za zadanie przygotowywać człowieka do pełnienia określonych ról w społeczeństwie, a nie spełniania jego zachcianek ${ }^{75}$. W czasach PRL-u nawet Dzień Dziecka miał charakter polityczno-propagandowy, a wyrazem nienawistnego stosunku do edukacji prowadzonej przez duchownych był zakaz katechizacji przez zakonników ${ }^{76}$.

Dziś, po transformacji ustrojowej, wciąż pojawiają się głosy mówiące, by wyrugować religię ze szkół, jako że wiara jest sprawą prywatną. Tymczasem okazuje się, że szkolnictwo katolickie nawet w najbardziej liberalnych krajach Europy, takich jak Holandia czy Belgia jest bardzo popularne - aż $60 \%$ uczniów uczęszcza w nich właśnie do katolickich

71 R. Czekalski, dz. cyt., s. 27.

72 Tamże.

73 T. Nowogrodzki, Psychologia rozwojowa, Warszawa 1954, s. 144-145.

${ }^{74}$ M. Krawczyk, Zasady wychowania moralnego, Warszawa 1958, s. 56.

${ }^{75}$ F. Adamski, Pedagogika chrześcijańska pedagogiką personalistyczną, „Paedagogia Christiana" 2013, nr 1/31, s. 108.

${ }^{76}$ Zob. K. Jaworska, Zakaz zatrudniania zakonników jako katechetów szkolnych, „Perspectiva. Legnickie Studia Teologiczno-Historyczne” 12 (2013), nr 2 (23) s. 237-242. 
placówek, a są one chwalone także przez przedstawicieli innych wyznań, takich jak hinduizm, buddyzm czy islam ${ }^{77}$. To właśnie katolicka etyka wychowawcza posiada środki, które czynią nauczanie skutecznym, ponieważ w prawdziwym nauczaniu chodzi nie tylko o przekazywanie wiedzy, ale także o przekazywanie wartości. Weryfikowalność wartości wywodzących się z etyki chrześcijańskiej ma swoje uzasadnienie w kontekście historycznym, a autorytet osób, które je przekazują, jest nie mniej ważny od nich samych. Słusznie konkludował papież Paweł VI, że dzisiejszy świat potrzebuje bardziej świadków niż nauczycieli. Jednak prawdziwy, skuteczny nauczyciel, chcąc zdobyć autorytet u swojego ucznia, musi być zarazem świadkiem. Jest to postawa osadzona na pewnych wartościach, będąca zapewne wyzwaniem dla dzisiejszych czasów.

\section{BIBLIOGRAFIA}

Amorth G., Wyznania egzorcysty, Częstochowa 1997.

Astrei G. i A., Diano O., Błędy mamy i taty. Praktyczny poradnik dla rodziców, Kraków 2013.

Badziukiewicz B., Sałasiński M., Vademecum wychowawcy, Warszawa 2005.

Bartnik Cz.S., Człowiek od poczęcia osoba, ,Teologia w Polsce” 2010, nr 4.

Brańka Z., Karanie i nagradzanie dzieci w rodzinie miejskiej, Kraków 2007.

Brynkus J., Ideologiczny kształt Dnia Dziecka w Polsce Ludowej, w: W kregu rodziny epok dawnych: dzieciństwo, red. B. Popiołek, A. Chłosta-Sikorska, M. Gadocha, Warszawa 2014.

Carron J., Sens czwartego przykazania i historia jego interpretacji, „Communio” 1996, nr 1 (91).

Chłodna I., Autorytet rodziny - dobro czy przeżytek? „Człowiek w kulturze” 2011/2012, nr 22.

Chrobak S. SDB, Podstawy pedagogiki nadziei : wspótczesne konteksty w inspiracji personalistyczno-chrześcijańskiej, Warszawa 2009.

Czekalski R., Personalistyczne postawy wychowania, Warszawa 2009.

Forward S., Toksyczni rodzice, Warszawa 2011.

Gilski M., Poczatkowe stadia życia ludzkiego wedtug Homera, „Polonia Sacra” 2013, nr 1 (32).

Grajewski J.L., Czcij rodziców, Łomża 1994.

77 http://gosc.pl/doc/2236111.Szkoly-katolickie-najpopularniejsze-w-UE (dostęp: 08.11.2014). 
Historia ojców i ojcostwa, red. J. Delumeau, D. Roche, Warszawa 1995.

Jaroszyński P., O autorytet nauczyciela, „Człowiek w kulturze” 2011/2012, nr 22.

Jaroszyński J., Autorytety w świecie stereotypów - krytyczna ocena medialnego obrazu osobowości, „Kultura-Media-Teologia” 2010, nr 3.

Jaworski P., Psychopedagogika - czyli jak psychologia zmienia szkołe, „Cywilizacja. O nauce, moralności, sztuce i religii” 2003, nr 7.

Juszczyk J., Przekazy medialne a czas wolny dzieci w wieku wczesnoszkolnym, w: Pedagogika szkolna $i$ wczesnoszkolna w sytuacji zmiany społecznej, kulturowej i oświatowej, red. S. Juszczyk, Katowice 2011.

Koclęga J., Funkcja mediów w komunikacji rodzinnej, w: Rodzina podmiotem wychowania i kreatorem komunikacji społecznej, red. N. Pikuła, Kraków 2010.

Kołodziej B., Wartość dziecka we współczesnym świecie, w: Oblicza dzieciństwa, red. D. Kornas-Biela, Lublin 2001.

Konopniuk T., Teologia „czwartej władzy”, w: Media wyznaniowe w Polsce 1989-2004, red. E. Kossewska, J. Adamowski, Warszawa 2004.

Kopeć E., Raport z przeprowadzonych badań dotyczacych diagnozy wiedzy pedagogicznej posiadanej przez rodziców dzieci $w$ wieku przedszkolnych $w$ powiecie kolbuszowskim, „Roczniki Pedagogiczne” 2013, t. 5 (45), nr 1.

Kosiński K., Czy potrzebujemy jeszcze autorytetów?, „Więź” 2001, nr 1 (507).

Kossewska, J. Adamowski, Warszawa 2004.

Krupiński W. SJ, Wychowywać miłością, Kraków 2001.

Mastalski J., Jak dobrze wychować dziecko?, Kraków 2009.

Melody P., Toksyczna miłość, Warszawa 2005;

Norwood R., Kobiety, które kochaja za bardzo, Poznań 2016.

Nowotka M., Kryzys współczesnej rodziny, „Wychowawca” 2014, nr 7.

Olbrycht K., Czy dorośli potrzebuja edukacji aksjologicznej?, w: Aksjologia edukacji dorostych, red. J. Kostkiewicz, Lublin 2004.

Pańpuch Z., Ideał nauczyciela-wychowawcy w pismach wybranych autorów starożytnych, "Zeszyty Edukacyjne” 2005, nr 3.

Pilch W, Człowiek w cywilizacji sieci, w: Logos i etos Cywilizacji zachodu, red. R. Kupczak, M. Jabłoński, Bielsko-Biała 2014.

Robaczewski A., O antropologię dla pedagogiki, „Cywilizacja. O nauce, moralności, sztuce i religii” 2003, nr 7.

Robaczewski A., O antropologie dla pedagogiki, „Cywilizacja” 2003, nr 7.

Sales M., Honor stawania się dzieckiem, czyli: co oznacza „Czcij ojca swego i matkę swoja”, „Communio” 1996, nr 1.

Salij J. OP, Szukającym drogi, Poznań 1993.

Sawicki M., Dziecko jest osobą. Szkice z teorii kształcenia $i$ wychowania, Warszawa 1995.

Szast M., Samotność w dobie cyfryzacji, „Pedagogika Katolicka” 2012, nr 2.

Tarasiewicz T., Pseudoautorytet zdemaskowany, „Człowiek w Kulturze” 2011/2012, nr 22.

Tomaselli G., Twarza w twarz z demonem. Nietypowy wywiad, Kraków 2015. 
Wilk J., Wychowawca wobec pytania: „Kim jest dziecko”, w: Oblicza dzieciństwa, red. D. Kornas-Biela, Lublin 2001.

Wrońska K., Osoba i wychowanie. Wokół personalistycznej filozofii wychowania Karola Wojtyły Jana Pawła II, Kraków 2000.

Zalewski D., Nauczyciel wobec ideologizacji szkoły, „Zeszyty Edukacyjne” nr 32005.

Zielińska J., Samokształcenie nauczycieli poprzez media, w: Kompetencje medialne społeczeństwa wiedzy, red. W. Strykowski, W. Skrzydlewski, Poznań 2004.

Ziemska M., Rodzina a osobowość, Warszawa 1979. 